\title{
Influence of Varieties and Integrated Nutrient Management on Yield Parameters of Isabgol (Plantago ovata Forsk.) under Northern Dry Zone of Karnataka, India
}

\author{
Siddalingayya V. Salimath", K. N. Kattimani Y. K. Kotikal, \\ Md Jameel Jhalegar, J. Venkatesh, D. R. Patile and N. S. Nagarja \\ College of Horticulture, Bagalkot \\ University of Horticultural Sciences, Bagalkot-587104, India \\ *Corresponding author
}

\begin{tabular}{|l|}
\hline Ke y w o r d s \\
Vallabh Isabgol-1 \\
and Gujarat \\
$\begin{array}{l}\text { Isabgol-2, Varieties, } \\
\text { INM treatments, } \\
\text { varieties with INM, } \\
\text { Growth, Yield }\end{array}$ \\
\hline Article Info \\
\hline $\begin{array}{l}\text { Accepted: } \\
\text { 20 August } 2019 \\
\text { Available Online: } \\
\text { 10 September } 2019\end{array}$ \\
\hline
\end{tabular}

\section{A B S T R A C T}

The field research was conducted to evaluate the performance of yield parameters of two Isabgol cultivars for commercial production in northern dry zone of Karnataka during two years 2015-16 and 2016-17. The experiment was laid out in split plot design (SPD) with sixteen INM treatment combinations at the College of Horticulture, Bagalkot. Analysis of both years with pooled data exhibited higher value was recorded in Vallabh Isabgol-1 in growth parameters viz., number of seeds per spike (60.33), seed yield per plot $\left(442.23 \mathrm{~g} \mathrm{plot}^{-1}\right)$, seed yield $\left(12.30 \mathrm{q} \mathrm{ha}^{-1}\right)$, husk yield $\left(3.62 \mathrm{q} \mathrm{ha}^{-1}\right)$, straw yield $\left(23.93 \mathrm{q} \mathrm{ha}^{-1}\right)$, harvest index $(23.93 \%)$, test weight $(2.25 \mathrm{~g})$ as compared to Gujarat Isabgol-2. Whereas the higher values with INM treatments with respect to plant growth parameters were observed in Viz. $\mathbf{N}_{11}-75 \%$ RD of FYM $\left(7.5 \mathrm{t} \mathrm{ha}^{-1}\right)+$ 75\% RD of NPK $\left(37.5: 18.75: 22.50 \mathrm{~kg} \mathrm{ha}^{-1}\right)+$ Azospirillum $\left(5 \mathrm{~kg} \mathrm{ha}^{-1}\right)+P S B\left(3 \mathrm{~kg} \mathrm{ha}^{-1}\right)$ $+\mathrm{ZnSO}_{4}\left(15 \mathrm{~kg} \mathrm{ha}^{-1}\right)+\mathrm{FeSO}_{4}\left(7.5 \mathrm{~kg} \mathrm{ha}^{-1}\right)$ viz., and number of seeds per spike (71.79), seed yield per plot $(555.66 \mathrm{~g})$, seed yield $\left(15.43 \mathrm{q} \mathrm{ha}^{-1}\right)$, husk yield $\left(5.38 \mathrm{q} \mathrm{ha}{ }^{-1}\right)$, straw yield (28.83 q ha $\left.{ }^{-1}\right)$, harvest index (22.13) and test weight $(2.57 \mathrm{~g})$. Higher values for interaction effect on growth parameters were recorded in $\mathrm{V}_{1} \mathrm{~N}_{11}$ viz, number of seeds per spike (72.50), seed yield per plot (557.97 g), seed yield (15.50 q ha $\left.{ }^{-1}\right)$, husk yield $\left(5.45 \mathrm{q} \mathrm{ha}^{-1}\right)$ straw yield $\left(29.30 \mathrm{q} \mathrm{ha}^{-1}\right)$, harvest index (22.34) and test weight (2.75 g).

\section{Introduction}

Isabgol is a sub-caulescent softy hairy or woolly annual herb it growing to a height of 30 to $50 \mathrm{~cm}$. Leaves are narrowly linear and distinctly toothed. Flowers are bisexual and favour out crossing due to protruding stigma,
45 to 70 in cylindric or ovoid, 2 to $4 \mathrm{~cm}$ long and about $0.5 \mathrm{~cm}$ broad spikes, capsules ellipsoidal about $8 \mathrm{~mm}$ long, obtuse, the upper half coming off as against blunt conical lid, membranous, glabrous, seeds ovoid-oblong, about $3 \mathrm{~mm}$ long, boat shaped, smooth, yellowish brown, contain a membranous cover 
and provide the husk on mechanical milling which constitutes the drug. The seeds are minute and 1000 seeds weighing about two grams. The husk is thin, white, membranous, and translucent covers the concave side of seeds (Farooqui and Sreeramu, 2001).

In India, Isabgol occupies an area of 80,000 ha with the total production of 45,000 tonnes and productivity of $0.56 \mathrm{MT} \mathrm{ha}^{-1}$. India is the only country with monopoly in Isabgol production and marketing in the international trade. Thus, with average export volume of 29,000 MT and it earns on an average of ₹ 520 crores annually which contribute to about 80 per cent of the Psyllium traded in the world market. So, it is called as dollar earning medicinal plant of India. Among all the countries in the world, the United States of America is the single major buyer of Psyllium husk from India, accounting for about 75 per cent of the total exports of the material from India (Goraya and Ved, 2019) with annual trade of more than 60,000 MT.

In Karnataka, Isabgol cultivation is very meager and only local cultivars are grown with poor yield. There is a wide yield gap between local cultivars and high yielding varieties. Performance of any crop or variety depends upon inherent genetic potential make up, of variety and response to climatic condition of the zone. To attain increased productivity, studies on INM have been carried out with an aim to identify suitable cultivar.

\section{Materials and Methods}

The experiment was conducted in the field at Department of Plantation Spices Medicinal and Aromatic Plants, College of Horticulture, Bagalkot at Haveli farm during the years 2015-16 and 2016-17. Geographically, this experimental site lies in Northern Dry Zone (Zone-3) of Karnataka state in the agro- climatic zone of Karnataka, situated at $16^{\circ}$ North latitude and $74^{\circ} 59^{\prime}$ East longitude and at an altitude of $533.0 \mathrm{~m}$ above mean sea level

The soil of experimental field was red clay loamy in texture, with percentages of sand 22.60 , silt 26.10 and clay52.20 bulk density $1.25, \mathrm{EC} 0.24 \mathrm{dS} \mathrm{m}^{-1}$ and $\mathrm{pH} 8.22$ (alkaline in reaction) with organic carbon 1.63 and available 268.02, 34.80, 273.69 NPK kg ha' . The source of seed collection was DMAPR Anandh Gujarat i.e. Vallabh Isabgol-1( $\left.\mathrm{V}_{1}\right)$ and Gujarat Isabgol-2 $\left(\mathrm{V}_{2}\right)$. Seed were sown in 18 November 2015 and 2016 with gross plot size of $3.6 \mathrm{~m} \mathrm{x} 1.5 \mathrm{~m}=5.40 \mathrm{~m}^{2}$ in split plot design in sixteen INM sub treatments with three replications as subplot listed below.

$\mathbf{N}_{1}$-RDF FYM (10 $\left.\mathrm{t} \mathrm{ha}^{-1}\right)+$ RDF NPK $\left(50: 25: 30 \mathrm{~kg} \mathrm{ha}^{-1}\right)$

$\mathbf{N}_{2}$-RDF FYM (0 $\left.\mathrm{t} \mathrm{ha}^{-1}\right)+$ RDF NPK $\left(50: 25: 30 \mathrm{~kg} \mathrm{ha}^{-1}\right)+\mathrm{ZnSo}_{4}\left(15 \mathrm{~kg} \mathrm{ha}^{-1}\right)$

$\mathbf{N}_{3}$-RDF FYM (10 $\left.\mathrm{t} \mathrm{ha}^{-1}\right)+$ RDF NPK $\left(50: 25: 30 \mathrm{~kg} \mathrm{ha}^{-1}\right)+\mathrm{FeSo}_{4}\left(7.5 \mathrm{~kg} \mathrm{ha}^{-1}\right)$

$\mathbf{N}_{4}$ RDF FYM (10 $\left.\mathrm{t} \mathrm{ha}^{-1}\right)+$ RDF NPK $\left(50: 25: 30 \mathrm{~kg} \mathrm{ha}^{-1}\right)+\mathrm{FeSo}_{4}\left(7.5 \mathrm{~kg} \mathrm{ha}^{-1}\right)+$ $\mathrm{ZnSo}_{4}\left(15 \mathrm{~kg} \mathrm{ha}^{-1}\right)$

$\mathbf{N}_{5}$-Vermicompost $\left(1 \mathrm{t} \mathrm{ha} \mathrm{ha}^{-1}\right)+$ RDF NPK (50:25:30 kg ha')

$\mathbf{N}_{6}$-Vermicompost $\left(1 \mathrm{t} \mathrm{ha}^{-1}\right)+50 \%$ RDF NPK $\left(50: 25: 30 \mathrm{~kg} \mathrm{ha}^{-1}\right)+$ Azospirillum $\left(5 \mathrm{~kg} \mathrm{ha}^{-1}\right)+$ Azotobacter $\left(5 \mathrm{~kg} \mathrm{ha}^{-1}\right)$

$\mathbf{N}_{7}-75 \%$ RDF FYM $\left(7.5 \mathrm{t} \mathrm{ha}^{-1}\right)+75 \%$ RDF NPK (37.5:18.75:22.50 kg ha-1)

$\mathbf{N}_{8}-75 \%$ RDF FYM $\left(7.5 \mathrm{t} \mathrm{ha}^{-1}\right)+75 \%$ RDF NPK (37.5:18.75:22.50 kg ha-1) + Azotobacter $(5 \mathrm{~kg}$ $\mathrm{ha}^{-1}$ ) $\mathbf{N}_{9}-75 \%$ RDF FYM (7.5 t ha $\left.{ }^{-1}\right)+75 \%$ RDF NPK (37.5:18.75:22.50 kg ha-1)+ Azospirillum $\left(5 \mathrm{~kg} \mathrm{ha}^{-1}\right)$

$\mathbf{N}_{10^{-}} 75 \%$ RDF FYM (7.5 t ha $\left.{ }^{-1}\right)+75 \%$ RDF NPK $\left(37.5: 18.75: 22.50 \mathrm{~kg} \mathrm{ha}^{-1}\right)+P S B(3 \mathrm{~kg}$ $\mathrm{ha}^{-1}$ )

$\mathbf{N}_{11-75 \% R D F}$ FYM $\left(7.5 \mathrm{tha}^{-1}\right)+75 \%$ RDF NPK $\quad\left(37.5: 18.75: 22.50 \quad \mathrm{~kg} \quad \mathrm{ha}^{-1}\right)+$ Azospirillum $\left(5 \mathrm{~kg} \quad \mathrm{ha}^{-1}\right)+P S B \quad\left(3 \mathrm{~kg} \quad \mathrm{ha}^{-}\right.$ 
$\left.{ }^{1}\right)+\mathrm{ZnSo}_{4}\left(15 \mathrm{~kg} \mathrm{ha}^{-1}\right)+\mathrm{FeSo}_{4}\left(7.5 \mathrm{~kg} \mathrm{ha}^{-1}\right)$ $\mathbf{N}_{12}-50 \%$ RDF FYM $\left(5 \mathrm{tha}^{-1}\right)+50 \%$ RDF NPK (25:12.5:15 NPK kg ha $\left.{ }^{-1}\right)$

$\mathbf{N}_{\mathbf{1 3}}-50 \%$ RD FYM $\left(5 \mathrm{tha}^{-1}\right)+50 \%$ RDF NPK $\left(25: 12.5: 15 \mathrm{~kg} \mathrm{ha}^{-1}\right)+$ Azotobacter $\left(5 \mathrm{~kg} \mathrm{ha}^{-1}\right)$ $\mathbf{N}_{14}-50 \%$ RDF FYM $\left(5 \mathrm{t} \mathrm{ha}^{-1}\right)+50 \%$ RDF NPK $\left(25: 12.5: 15 \mathrm{~kg} \mathrm{ha}^{-1}\right)+$ Azospirillum $\left(5 \mathrm{~kg} \mathrm{ha}^{-1}\right)$ $\mathbf{N}_{15}-50 \%$ RDF FYM $\left(5 \mathrm{t} \mathrm{ha}^{-1}\right)+50 \%$ RDF NPK $\left(25: 12.5: 15 \mathrm{~kg} \mathrm{ha}^{-1}\right)+P S B\left(3 \mathrm{~kg} \mathrm{ha}^{-1}\right)$ $\mathbf{N}_{16}-50 \%$ RD FYM $\left(5 \mathrm{tha}^{-1}\right)+75 \%$ RDF NPK $\left(37.5: 18.75: 22.50 \mathrm{~kg} \mathrm{ha}^{-1}\right)+$ Azospirillum $(5 \mathrm{~kg}$ $\left.\mathrm{ha}^{-1}\right)+P S B \quad\left(3 \mathrm{~kg} \mathrm{ha}^{-1}\right)+\mathrm{Znso}_{4} \quad\left(15 \mathrm{~kg} \quad \mathrm{ha}^{-}\right.$ $\left.{ }^{1}\right)+\mathrm{FeSo}_{4}\left(7.5 \mathrm{~kg} \mathrm{ha}^{-1}\right)$.

The experiment after layout then treatments were applied as per above nutrient combination, then mixed thoroughly in plots before imposing the treatments. Zinc was applied in the form of $\mathrm{ZnSO}_{4}$ at the time of sowing half dose of $\mathrm{N}$ was applied as a basal and remaining half was applied one month after sowing as top dressing full dose of $\mathrm{P}$ and $\mathrm{K}$ were applied at the time of sowing below the seed in furrows made with the help of land hoe. Manual thinning weeding and hoeing were done at one month after sowing to provide an ideal environment to the crop a light irrigation was given immediately before sowing, however six and seven irrigation were given as pet requirement of the crop with the help of sprinkler.

Five plants were selected randomly in each plot, were recorded dry matter of plants per meter row length growth parameter were recorded at the time of harvest in each plot at all the stages of crop however the yield parameters were recorded at harvest stages values were discussed here. The grain and straw samples were collected separately from each plot, dried at $60{ }^{\circ} \mathrm{C}$ for 48 hours. Dry mass was ground in a stainless steel ball mill for nutrient analysis. $\mathrm{N}$ concentration in both seed and straw was estimated by modified Kjeldahal's method (Piper,1966). The P content was determined using the vanado molybdo phosphoric acid yellow colour method (Jackson 1973), K content was estimated with diacid mixture by using Flame photometer (Stanford, S. and English., 1963).

Number of seeds per spike: The seed number was recorded for five spikes from each of five labelled plants from each plot and their average value was taken for the analysis.

Seed yield per plot (g): The net plot was harvested and threshed. The weight of the seeds of net plot was recorded in gram per plot yield.

Seed yield $\left(\mathrm{q} \mathrm{ha}^{-1}\right)$ : The net plot was harvested and threshed and weight of the seeds of net plot was recorded and was converted into seed yield quintal per hectare.

Husk yield $\left(\mathrm{q} \mathrm{ha}^{-1}\right)$ : As a preliminary step, the husk content $(\%)$ of the seeds of the samples belonging to different nutrient treatments was determined as per the procedure given by Patel et al., (2005). To determine the husk content, one gram seed of respective sample was taken and was boiled with mild acid $(0.1 \mathrm{~N} \mathrm{HCl})$ for two minutes and subsequently washed nine times with hot $\left(80^{\circ} \mathrm{C}\right)$ distilled water, each time using $10 \mathrm{ml}$. Total removal of mucilage was judged by the non-stickiness of the seeds. The husk yield per hectare was worked out by multiplying the total unhusked seed yield per hectare with the husk content in the seeds.

Straw yield $\left(\mathrm{q} \mathrm{ha}^{-1}\right)$ : The crop of the net plot was harvested and threshed after separating from the seeds; the straw was dried under shade and then converted into straw yield as quintals per hectare.

Harvest Index (\%): The harvest index was calculated by dividing economic yield (seed yield) per hectare by total biological yield per 
hectare on dry weight basis and it was expressed in percentage.

Test weight (g): The observations on the weight of 1000 seeds (g) were recorded after harvest in each of the treatment combination.

The pooled data was subjected to statistical analysis of split-plot design by the Fischer's method of analysis of variance technique as given by Panse and Sukhatme (1983). The level of significance used in ' $F$ ' and ' $t$ ' test was $\mathrm{p}=0.05$, critical values were calculated wherever the ' $F$ ' test was significant.

\section{Results and Discussion}

At harvest stage yield parameters were recorded significantly higher values were recorded with Vallabh Isabgol-1, number of seeds per spike (60.33), seed yield per plot $(442.23 \mathrm{~g})$, seed yield $\left(12.30 \mathrm{q} \mathrm{ha}^{-1}\right)$, husk yield (3.62 q ha-1), straw yield (23.93 q ha-1), harvest index (18.11\%) and test weight $(2.57 \mathrm{~g})$ during pooled data respectively. This results due to varietal performance to different agroclimatic conditions and genetical characteristics of particular variety and their difference in genotypic factor and adaptability of particular variety to soil and climatic conditions and the increased number of leaves, leaf area and number of tillers helped in better synthesis of carbohydrates and their utilization for build up of new cells, apart from better absorption of nutrients resulting in increased dry matter production were reported by several workers (Kumar et al., 2009, Shirvan et al., 2016a and Tyagi et al., 2016) and also quality parameters this may be due to genotypic factor same findings was reported by Raissi et al., (2013). The lower number of seeds per spike (58.03), seed yield per plot (397.85), seed yield $\left(11.05 \mathrm{q} \mathrm{ha} \mathrm{h}^{-1}\right)$, husk yield (3.33 q ha $\left.{ }^{-1}\right)$, straw yield (20.00 q ha $\left.{ }^{-1}\right)$, harvest index (15.53\%), test weight (2.21g) as campared to in Gujarat Isabgol-2 during pooled data.

\section{Integrated nutrient management}

The significantly higher number of seeds per plant, at harvest (71.79) was recorded in $\mathrm{N}_{11}$ which was on par with $\mathrm{N}_{6}(66.95), \mathrm{N}_{16}$ (66.70) and $\mathrm{N}_{4}$ (65.76). The significantly lower number of tillers per plant was recorded in $\mathrm{N}_{13}$ (47.72). This has been the consequence as a result of higher nutrient availability with application of organic manure (FYM, VC and biofertilizers) along with inorganic fertilizers which had profound influence in mobilizing the nutrients from the unavailable form of nutrients to available source and also enhanced improvement of soil physical, chemical and biological properties. The micro nutrient zinc application along with organics it acts as a component of carbonic anhydrase, as well as several dehydrogenases and required for auxin production which in turn enhance plant growth.

Iron was necessary for the biosynthesis of chlorophyll and cytochrome, leading to increase in photosynthesis processes, respiration, other biochemical physiological activities of the plants. Similar results observed by Yadav et al., (2003) Salmasi et al., (2012) and Tripathi et al., (2013).

Significantly higher seed yield per plot and seed yield per plot and hectare in pooled analysis were presented $555.66 \mathrm{~g} \mathrm{plot}^{-1}, 15.43$ $\mathrm{q} \mathrm{ha}{ }^{-1}$ was recorded in $\mathrm{N}_{11}$ (75\% RD of FYM $+75 \% \mathrm{RD}$ of NPK + Azospirillum + PSB + $\mathrm{ZnSO}_{4}+\mathrm{FeSO}_{4}$ ), which were on par with $\mathrm{N}_{6}$ (Vermicompost $+50 \%$ RD of NPK + Azospirillum + Azatobacter) (533.81 g,14.83 q $\mathrm{ha}^{-1}$ ) and $\mathrm{N}_{4}$ (RD of FYM + RD of NPK+ $\left.\mathrm{ZnSO}_{4}+\mathrm{FeSO}_{4}\right)\left(540.91 \mathrm{~g}, 15.12 \mathrm{q} \mathrm{ha}^{-1}\right), \mathrm{N}_{16}$ (50\% RD of FYM+ $75 \%$ RD of NPK + Azospirillum $+P S B+\mathrm{ZnSO}_{4}+\mathrm{FeSO}_{4}$ ) 
(536.34 g, $14.90 \mathrm{q} \mathrm{ha}^{-1}$ ). Further lower seed yield (332.92g and 9.25 $\mathrm{q} \mathrm{ha}^{-1}$ ) seed yield plot ${ }^{-}$ ${ }_{1}^{1}$ and seed yield ha ${ }^{-1}$ was recorded in $\mathrm{N}_{13}(50 \%$ $\mathrm{RD}$ of FYM $+50 \% \mathrm{RD}$ of NPK+ Azatobacter) during pooled data, which could be due to the increased seed yield consequence with application of balanced nutrient RD of FYM $75 \%+\mathrm{RD}$ of NPK micro nutrients mixed with bio fertilizers like azospirillum mechanism through phosphate dissolution and in the biosynthesis of bio-active in soil. The biofertilizers help in fixation of atmospheric nitrogen, better root proliferation, better availability and absorption of nutrients by the plants, which might have resulted in better growth in plant further $\mathrm{N} \mathrm{P} \mathrm{K} \mathrm{nutrients}$ available form would attributed to more uptake of nutrients in faster rate in plant, $P S B$ helps in reducing phosphorus fixation by its chelating effect and also solubilized the fixed phosphorus accelerated increase in growth of parameters towards reproductive parameters with accelerating tillers, dry matter production, number of spikes per plant, spikelets per plant, spike length, increase towards yield attributing characters viz. number of seeds per spike, ultimately all these growth and reproductive and yield attributes helped to increase seed yield, Similar findings observed by Repsiene (2001), Yadav et al., (2003), Nadim et al., (2011), Singh et al., (2011), Tripati et al., (2013), Choudhary et al., (2014), Nadukeri et al., (2014) and Shivran et al., (2015).

Higher husk yield $\left(\mathrm{q} \mathrm{ha} \mathrm{h}^{-1}\right.$ ) was significantly influenced by integrated nutrient management (5.38 $\mathrm{q} \mathrm{ha}^{-1}$ ) was recorded in $\mathrm{N}_{11}$, which was on par with $\mathrm{N}_{4}$ (5.20), $\mathrm{N}_{6}$ (5.14), and $\mathrm{N}_{16}$ (5.01). Further the lower number of leaves per plant was recorded in $\mathrm{N}_{13}$ (2.38). This is because of combined application of nutrients resulted creation of favourable environment for uptake of nutrients for plants by use organic and inorganic nutrients along with Azospirillum and PSB around rhizosphere which attributed to the enhanced the availability nutrients at appropriate time leads to the production of growth promoting substances, further that might have caused cell elongation and multiplication then to increase in the chlorophyll content of leaves resulted in increased synthesis of carbohydrates Yadav et al., (2003).

Significantly higher straw yield, (28.83 q ha $\left.{ }^{-1}\right)$ was recorded in $\mathrm{N}_{11}$ (75\% RD of FYM + 75 $\% \mathrm{RD}$ of $\mathrm{NPK}+$ Azospirillum $+P S B+\mathrm{ZnSO}_{4}$ $+\mathrm{FeSO}_{4}$ ) which was on par with $\mathrm{N}_{16}$ (28.29), $\mathrm{N}_{6}$ (28.25) and $\mathrm{N}_{6}$ (27.77). Whereas the lower (17.10) straw yield recorded in $\mathrm{N}_{13}$ during pooled data same findings reported by Patel and Saravanan (2010) and Shivran et al., (2016 a).

The significantly higher harvest index (22.13 $\%)$ was recorded in $\mathrm{N}_{11}(75 \% \mathrm{RD}$ of $\mathrm{FYM}+$ $75 \% \mathrm{RD}$ of $\mathrm{NPK}+$ Azospirillum $+P S B+$ $\mathrm{ZnSO}_{4}+\mathrm{FeSO}_{4}$ ) which was on par with $\mathrm{N}_{16}$ (21.60), $\mathrm{N}_{6}$ (21.54) and $\mathrm{N}_{4}\left(21.47 \mathrm{q} \mathrm{ha}^{-1}\right)$. Further the lower harvest index $\mathrm{N}_{13}(13.17 \mathrm{q}$ $\left.\mathrm{ha}^{-1}\right)$. The PSB helps in reducing phosphorus fixation by its chelating effect and also solubilized the fixed phosphorus leading to more uptakes of nutrients and reflected in better yield attributes like higher seed and straw yield. Higher economic and biological yield contributed towards increase harvest index these findings are in line with (Nadim et al., 2011).

The significantly higher test weight $(2.57 \%)$ was recorded in $\mathrm{N}_{11}(75 \% \mathrm{RD}$ of FYM $+75 \%$ $\mathrm{RD}$ of NPK + Azospirillum $+P S B+\mathrm{ZnSO}_{4}+$ $\mathrm{FeSO}_{4}$ ) which was on par with $\mathrm{N}_{4}(2.49), \mathrm{N}_{6}$ (2.49 $\mathrm{q} \mathrm{ha}^{-1}$ ) and $\mathrm{N}_{16}(2.45)$. Further the lower harvest index $\mathrm{N}_{13}\left(1.76 \mathrm{q} \mathrm{ha}^{-1}\right)$ because of higher seed weight due to higher doses of nutrients use, leads to increase higher functional photosynthetic accumulation, which in turn have resulted in increased seed size and seed filling further then the higher husk yield 
same findings reported by Nadim et al., (2011), Singh et al., (2011) and Tripati et al., (2013).

\section{Interaction effect}

Interaction effect significantly higher seed yield (15.50 q ha ${ }^{-1}$ ) was recorded in Vallabh Isabgol-1 supplied of $\mathrm{N}_{11}$ (75\% RD of FYM + $75 \%$ of RD NPK + Azospirillum + PSB + $\mathrm{ZnSO}_{4}+\mathrm{FeSO}_{4}$ ), which was on par with $\mathrm{V}_{2} \mathrm{~N}_{16}\left(15.32 \mathrm{q} \mathrm{ha}^{-1}\right), \mathrm{V}_{1} \mathrm{~N}_{16}\left(15.32 \mathrm{q} \mathrm{ha}^{-1}\right)$, $\mathrm{V}_{1} \mathrm{~N}_{4}\left(15.19 \mathrm{q} \mathrm{ha}^{-1}\right)$ and $\mathrm{V}_{1} \mathrm{~N}_{6}\left(15.08 \mathrm{q} \mathrm{ha}^{-1}\right)$. The lower seed yield $\left(8.54 \mathrm{q} \mathrm{ha}^{-1}\right)$ was recorded in $\mathrm{V}_{2} \mathrm{~N}_{13}$ during pooled data This was attributed to genotypic variation of that variety and proper vegetative development by plants and differences in soil, agroclimatic condition then suitability of variety to that region and balanced application of 75 percentage of fertilizer doses with organics and micro nutrients application leads to plant to take adequate nutrition at optimum growth stage helps for plant more available NPK plant at faster rate, which leads to plant to absorb optimum nutrients, leads to increased in number of tillers and spikes per plant and spike length these findings leads to more longer period of vegetative growth parameters resulting in enhanced photosynthetic and metabolic activities then consequently enabling the plants to bear more spikes of longer size, and spike length with application organics along with $P S B$ treatments, which in turn played an important role in rapid celldivision and elongation in the meristamatic regions, root development and proliferation of enhancing early and more flowering, results increase, in number spikes, spikelets per plant same findings observed by Hindiholi (2006), Kumar et al., (2015) and Shivran et al., (2016 b). Interaction effect significant higher husk yield (5.45 q ha ${ }^{-1}$ ) was recorded with $\mathrm{V}_{1}$ supplied with $\mathrm{N}_{11}(75 \%$ RD of FYM $+75 \%$ $\mathrm{RD}$ of $\mathrm{NPK}+$ Azospirillum $+P S B+\mathrm{ZnSO}_{4}+$ $\left.\mathrm{FeSO}_{4}\right)$ which was on par with $\mathrm{V}_{1} \mathrm{~N}_{4}(5.32 \mathrm{q}$ $\left.\mathrm{ha}^{-1}\right), \mathrm{V}_{1} \mathrm{~N}_{6}\left(5.31 \mathrm{q} \mathrm{ha}^{-1}\right), \mathrm{V}_{2} \mathrm{~T}_{11}$ (5.30), and $\mathrm{V}_{1} \mathrm{~N}_{16}\left(5.08 \mathrm{q} \mathrm{ha}^{-1}\right)$. Whereas lower husk yield $\left(2.30 \mathrm{q} \mathrm{ha}{ }^{-1}\right)$ was recorded in $\mathrm{V}_{2} \mathrm{~N}_{13}$ during pooled data. This increased yield parameters due to use of improved variety because of genotypic character and increased the growth parameters conversion towards yield parameters with integrated use of chemical fertilizer, manures like FYM enhances the uptake of $\mathrm{N}, \mathrm{P}$ and $\mathrm{K}$ by process releasing humus forming microbes. Azotobactor has nitrogen fixing potential as Nitrogenase activity of rhizosphere in soils by releasing some growth regulators IAA, results in the production of more vegetative growth parameters conversion towards physiological then reproductive. This relationship helped to increase the yield attributes, these characters had positive beneficial effect towards higher seed yield and husk yield same findings revealed by Hindiholi et al., (2006), Chaudhary and Shivran et al., (2009), Saxena and Rao (2000), Shivran et al., (2015) and Shivran et al., (2016b). INM effect significantly number of straw yield $(29.30 \mathrm{~kg}$ $\mathrm{ha}^{-1}$ ) was recorded in Vallabh Isabgol-1 supplied of $\mathrm{N}_{11}(75 \% \mathrm{RD}$ of FYM $+75 \%$ of $\mathrm{RD} \mathrm{NPK}+$ Azospirillum $+P S B+\mathrm{ZnSO}_{4}+$ $\mathrm{FeSO}_{4}$ ), which was on par with $\mathrm{V}_{2} \mathrm{~N}_{11}(28.35)$, $\mathrm{V}_{1} \mathrm{~N}_{6}$ (28.46), $\mathrm{V}_{1} \mathrm{~N}_{16} \quad$ (28.29) and $\mathrm{V}_{1} \mathrm{~N}_{4}$ (28.16). The lower harvest index (15.37) was recorded in $\mathrm{V}_{1} \mathrm{~N}_{13}$ during pooled data.. This might be due to use of improved variety with its genotypic character and a balance way of Integrated Nutrient Management leading to increased growth, physiological, reproductive parameters leads to more uptake of NPK, source to sink. This relationships helped to increase the seed yield of identical characters reported by Shivran et al., (2016b). This was increased due to use of improved variety with integrated use of chemical fertilizer, manures helps to increase the straw yield and biological yield of Isabgol FYM enhances the uptake of $\mathrm{N}, \mathrm{P}$ and $\mathrm{K}$ by releasing humus forming microbes. 
Table.1 Yield parameters on number of seeds spike and seed yield $\operatorname{plot}^{-1}(\mathrm{~g})$ as influenced by Isabgol varieties and integrated nutrient management

\begin{tabular}{|c|c|c|c|c|c|c|c|c|c|c|c|c|c|c|c|c|c|c|c|c|c|c|c|c|c|c|c|c|c|c|c|c|c|c|c|c|c|}
\hline \multirow{3}{*}{$\begin{array}{l}\begin{array}{l}\text { Varieties } \\
\text { Nutrients }\end{array} \\
\text { Nutrients }\end{array}$} & \multicolumn{9}{|c|}{ Number of seeds spike } & \multicolumn{9}{|c|}{ seed yield per plot (g) } & \multicolumn{9}{|c|}{ Seed yield $\left(\mathbf{q ~ h a}^{-1}\right)$} & \multicolumn{10}{|c|}{ Husk yield $\left(\mathbf{q} \mathbf{a}^{-1}\right)$} \\
\hline & \multicolumn{3}{|c|}{2015} & \multicolumn{3}{|c|}{2016} & \multicolumn{3}{|c|}{ Pooled data } & \multicolumn{3}{|c|}{2015} & \multicolumn{3}{|c|}{2016} & \multicolumn{3}{|c|}{ Pooled data } & \multicolumn{3}{|c|}{2015} & \multicolumn{3}{|c|}{2016} & \multicolumn{3}{|c|}{ Pooled data } & \multicolumn{4}{|c|}{2015} & \multicolumn{3}{|c|}{2015} & \multicolumn{3}{|c|}{ Pooled data } \\
\hline & $\mathbf{v}_{\mathbf{1}}$ & $\mathbf{v}_{\mathbf{1}}$ & Mean & $\mathbf{v}_{1}$ & $\mathrm{v}_{1}$ & Mean & $\mathrm{v}_{\mathbf{1}}$ & $\mathrm{v}_{1}$ & Mean & $\mathrm{v}_{\mathbf{1}}$ & $\mathrm{v}_{1}$ & Mean & $v_{1}$ & $\mathbf{v}_{1}$ & Mean & $\mathrm{v}_{1}$ & $v_{1}$ & Mean & $v_{1}$ & $\mathrm{v}_{1}$ & Mean & $\mathbf{V}_{1}$ & $\mathbf{v}_{2}$ & Mean & $\mathrm{v}_{1}$ & $\mathbf{V}_{2}$ & Mean & $\mathbf{v}_{\mathbf{1}}$ & $\mathbf{v}_{2}$ & Mea & & $\mathrm{V}_{\mathbf{1}}$ & $\mathbf{v}_{2}$ & Mean & $v_{1}$ & $\mathbf{V}_{2}$ & Mean \\
\hline $\mathrm{N}_{1}$ & 61.07 & 61.07 & 61.07 & 61.67 & 60.00 & 60.83 & 61.37 & 59.75 & 60.56 & 465.33 & 346.33 & 405.83 & 449.48 & 342.90 & 396.19 & 465.33 & 346.33 & 405.83 & 12.05 & 9.43 & 61.07 & 12.93 & 9.62 & 11.27 & 12.49 & 9.52 & 11.01 & 3.12 & 2.4 & 2.7 & & 3.60 & 2.48 & 3.04 & 3.36 & 2.46 & 2.91 \\
\hline $\mathbf{N}_{2}$ & 62.08 & 62.08 & 62.08 & 63.33 & 47.67 & 55.50 & 62.71 & 47.42 & 55.06 & 476.03 & 352.97 & 414.50 & 463.13 & 347.35 & 405.24 & 476.03 & 352.97 & 414.50 & 12.51 & 9.49 & 62.08 & 13.22 & 9.80 & 11.51 & 12.86 & 9.65 & 11.26 & 3.70 & 2.8 & 3.2 & & 3.43 & 2.92 & 3.17 & 3.56 & 2.87 & 3.22 \\
\hline $\mathrm{N}_{3}$ & 68.12 & 68.12 & 68.12 & 68.67 & 41.33 & 55.00 & 68.40 & 41.20 & 54.80 & 447.52 & 436.97 & 442.24 & 436.01 & 431.70 & 433.86 & 447.52 & 436.97 & 442.24 & 11.79 & 11.85 & 68.12 & 12.43 & 12.14 & 12.28 & 12.11 & 11.99 & 12.05 & 2.48 & 3.6 & 3.0 & & 2.62 & 3.70 & 3.16 & 2.55 & 3.69 & 3.12 \\
\hline $\mathrm{N}_{4}$ & 66.10 & 66.10 & 66.10 & 68.67 & 67.67 & 68.17 & 67.39 & 64.13 & 65.76 & 546.55 & 548.09 & 547.32 & 540.32 & 541.49 & 540.91 & 546.55 & 548.09 & 547.32 & 14.84 & 14.86 & 66.10 & 15.55 & 15.22 & 15.39 & 15.19 & 15.04 & 15.12 & 5.16 & 5.1 & 5.1 & & 5.48 & 4.96 & 5.22 & 5.32 & 5.07 & 5.20 \\
\hline $\mathbf{N}_{\mathrm{s}}$ & 55.95 & 55.95 & 55.95 & 55.33 & 56.67 & 56.00 & 55.64 & 56.42 & 56.03 & 391.89 & 381.03 & 386.46 & 386.04 & 379.34 & 382.69 & 391.89 & 381.03 & 386.46 & 10.56 & 10.49 & 55.95 & 10.89 & 10.58 & 10.73 & 10.72 & 10.54 & 10.63 & 2.49 & 2.8 & 2.6 & & 2.75 & 2.87 & 2.81 & 2.62 & 2.86 & 2.74 \\
\hline $\mathrm{N}_{6}$ & 66.93 & 66.93 & 66.93 & 68.00 & 66.67 & 67.33 & 67.47 & 66.44 & 66.95 & 550.59 & 516.13 & 533.36 & 543.00 & 524.61 & 533.81 & 550.59 & 516.13 & 533.36 & 14.87 & 14.81 & 66.93 & 15.29 & 14.34 & 14.82 & 15.08 & 14.57 & 14.83 & 5.11 & 5.0 & 5.0 & & 5.52 & 4.90 & 5.21 & 5.31 & 4.96 & 5.14 \\
\hline $\mathbf{N}_{7}$ & 65.67 & 65.67 & 65.67 & 56.00 & 63.00 & 59.50 & 60.83 & 62.82 & 61.83 & 388.69 & 329.00 & 358.84 & 380.26 & 326.43 & 353.35 & 388.69 & 329.00 & 358.84 & 10.33 & 9.00 & 65.67 & 10.80 & 9.14 & 9.97 & 10.56 & 9.07 & 9.82 & 2.87 & 2.6 & 2.7 & & 3.02 & 2.69 & 2.85 & 2.94 & 2.69 & 2.82 \\
\hline $\mathrm{N}_{8}$ & 58.80 & 58.80 & 58.80 & 57.67 & 59.67 & 58.67 & 58.23 & 59.36 & 58.79 & 370.39 & 310.33 & 340.36 & 367.66 & 324.06 & 345.86 & 370.39 & 310.33 & 340.36 & 10.14 & 9.38 & 58.80 & 10.29 & 8.62 & 9.45 & 10.21 & 9.00 & 9.61 & 2.73 & 2.2 & 2.5 & & 2.76 & 2.10 & 2.43 & 2.75 & 2.19 & 2.47 \\
\hline $\mathbf{N}$ & 49.00 & 49.00 & 49.00 & 48.00 & 61.33 & 54.67 & 48.50 & 60.99 & 54.74 & 361.13 & 337.30 & 349.21 & 362.32 & 333.61 & 347.97 & 361.13 & 337.30 & 349.21 & 10.10 & 9.16 & 49.00 & 10.03 & 9.37 & 9.70 & 10.06 & 9.27 & 9.67 & 2.81 & 2.7 & 2.7 & & 2.79 & 2.80 & 2.80 & 2.80 & 2.76 & 2.78 \\
\hline$N_{10}$ & 50.37 & 50.37 & 50.37 & 57.33 & 48.33 & 52.83 & 53.85 & 48.10 & 50.98 & 366.37 & 340.99 & 353.68 & 369.70 & 341.54 & 355.62 & 366.37 & 340.99 & 353.68 & 10.36 & 9.50 & 50.37 & 10.18 & 9.47 & 9.82 & 10.27 & 9.49 & 9.88 & 2.75 & 2.5 & 2.6 & & 2.69 & 2.57 & 2.63 & 2.72 & 2.57 & 2.65 \\
\hline $\mathbf{N}_{11}$ & 71.33 & 71.33 & 71.33 & 73.67 & 71.67 & 72.67 & 72.50 & 71.08 & 71.79 & 563.61 & 558.93 & 561.27 & 557.97 & 553.34 & 555.66 & 563.61 & 558.93 & 561.27 & 15.34 & 15.22 & 71.33 & 15.66 & 15.53 & 15.59 & 15.50 & 15.37 & 15.43 & 5.35 & 5.1 & 5.2 & & 5.55 & 5.41 & 5.48 & 5.45 & 5.30 & 5.38 \\
\hline$N_{12}$ & 60.40 & 60.40 & 60.40 & 61.00 & 55.00 & 58.00 & 60.70 & 54.67 & 57.68 & 455.96 & 343.56 & 399.76 & 456.26 & 343.93 & 400.09 & 455.96 & 343.56 & 399.76 & 12.68 & 9.56 & 60.40 & 12.67 & 9.54 & 11.10 & 12.67 & 9.55 & 11.11 & 3.41 & 2.6 & 3.0 & & 3.74 & 2.68 & 3.21 & 3.57 & 2.69 & 3.13 \\
\hline$N_{13}$ & 44.17 & 44.17 & 44.17 & 44.00 & 51.50 & 47.75 & 44.08 & 51.35 & 47.72 & 358.40 & 313.67 & 336.03 & 358.28 & 307.55 & 332.92 & 358.40 & 313.67 & 336.03 & 9.95 & 8.37 & 44.17 & 9.96 & 8.71 & 9.33 & 9.95 & 8.54 & 9.25 & 2.36 & 2.2 & 2.3 & & 2.54 & 2.35 & 2.45 & 2.45 & 2.30 & 2.38 \\
\hline$N_{14}$ & 54.50 & 54.50 & 54.50 & 55.00 & 58.33 & 56.67 & 54.75 & 58.15 & 56.45 & 360.93 & 353.73 & 357.33 & 361.37 & 349.38 & 355.38 & 360.93 & 353.73 & 357.33 & 10.05 & 9.58 & 54.50 & 10.03 & 9.83 & 9.93 & 10.04 & 9.70 & 9.87 & 2.96 & 2.5 & 2.7 & & 2.96 & 2.94 & 2.95 & 2.96 & 2.74 & 2.85 \\
\hline$N_{15}$ & 59.50 & 59.50 & 59.50 & 60.00 & 62.67 & 61.33 & 59.75 & 62.25 & 61.00 & 457.33 & 402.47 & 429.90 & 492.34 & 397.12 & 444.73 & 457.33 & 402.47 & 429.90 & 14.65 & 10.88 & 59.50 & 12.70 & 11.18 & 11.94 & 13.68 & 11.03 & 12.35 & 4.71 & 3.1 & 3.9 & & 4.08 & 3.25 & 3.67 & 4.40 & 3.21 & 3.80 \\
\hline $\mathbf{N}_{16}$ & 68.77 & 68.77 & 68.77 & 69.33 & 67.33 & 68.33 & 69.05 & 64.36 & 66.70 & 557.00 & 510.16 & 533.58 & 551.48 & 521.19 & 536.34 & 557.00 & 510.16 & 533.58 & 15.17 & 14.78 & 68.77 & 15.47 & 14.17 & 14.82 & 15.32 & 14.48 & 14.90 & 5.03 & 5.0 & 5.0 & & 5.13 & 4.84 & 4.99 & 5.08 & 4.93 & 5.01 \\
\hline \multirow[t]{2}{*}{ MEAN } & 60.17 & 60.17 & 60.17 & 60.48 & 58.68 & & 60.33 & 58.03 & & 444.86 & 398.85 & & 442.23 & 397.85 & & 444.86 & 398.85 & & 12.21 & 11.02 & 60.17 & 12.38 & 11.08 & & 12.30 & 11.05 & & 3.57 & 3.3 & & & 3.67 & 3.34 & & 3.62 & 3.33 & \\
\hline & $\begin{array}{c}\text { S.Em } \\
\pm\end{array}$ & & $5 \%$ & $\begin{array}{c}\text { S.Em } \\
\pm\end{array}$ & CD at & & $\begin{array}{c}\text { S.Em } \\
\pm\end{array}$ & & at $5 \%$ & $\begin{array}{c}\text { S.Em } \\
\pm\end{array}$ & CD at & & $\begin{array}{c}\text { S.Em } \\
\pm\end{array}$ & CD at & & $\begin{array}{c}\text { S.Em } \\
\pm\end{array}$ & CD a & & $\underset{ \pm}{\text { S.Em }}$ & S.En & & $\underset{ \pm}{\text { S.Em }}$ & S.En & $\mathrm{m} \pm$ & $\stackrel{\text { S.Em }}{ \pm}$ & & Dat 5\% & $\underset{ \pm}{\text { S.Em }}$ & & S.Em \pm & & $\stackrel{\text { S.Em }}{ \pm}$ & & $\mathbf{E m} \pm$ & $\stackrel{\text { S.Em }}{ \pm}$ & & D at $5 \%$ \\
\hline Varieties (V) & 0.76 & & s & 0.48 & $\mathrm{Ns}$ & & 0.53 & & vs & 2.81 & 8.56 & & 3.62 & 11.0 & & 2.81 & 8.5 & & 0.16 & 0.4 & & 0.08 & 0.2 & .24 & 0.09 & & 0.29 & 0.06 & & NS & & 0.11 & & NS & 0.08 & & NS \\
\hline Nutrients $(\mathrm{N})$ & 2.53 & & & 2.32 & 6.5 & & 2.27 & & .42 & 12.52 & 35.4 & & 10.10 & 28.5 & & 12.52 & 35. & & 0.36 & 1.0 & & 0.35 & 1.0 & 00 & 0.28 & & 0.79 & 0.18 & & 0.51 & & 0.17 & & 0.50 & 0.15 & & 0.45 \\
\hline $\mathrm{N}$ at same $\mathrm{V}$ & 3.57 & & 32 & 3.29 & 9.3 & & 3.21 & & .08 & 17.70 & 50.0 & & 14.28 & 40.4 & & 17.70 & 50. & & 0.51 & 1.4 & & 0.50 & 1.4 & 41 & 0.39 & & 1.12 & 0.25 & & 0.72 & & 0.25 & & 0.71 & 0.22 & & 0.63 \\
\hline $\begin{array}{l}\text { Vat same or } \\
\text { different } N\end{array}$ & 3.09 & & 81 & 2.05 & 5.8 & & 2.22 & & .29 & 11.76 & 33.2 & & 14.48 & 40.9 & & 11.76 & 33. & & 0.63 & 1.8 & & 0.33 & 0.9 & & 0.38 & & 1.07 & 0.26 & & 0.75 & & 0.46 & & 1.31 & 0.33 & & 0.94 \\
\hline
\end{tabular}


Table.2 Yield parameters on straw yield $\left(\mathrm{q} \mathrm{ha}^{-1}\right)$, harvest index $(\mathrm{HI} \%)$ and Test weight $(\mathrm{g})$ as influenced by Isabgol varieties and integrated nutrient management

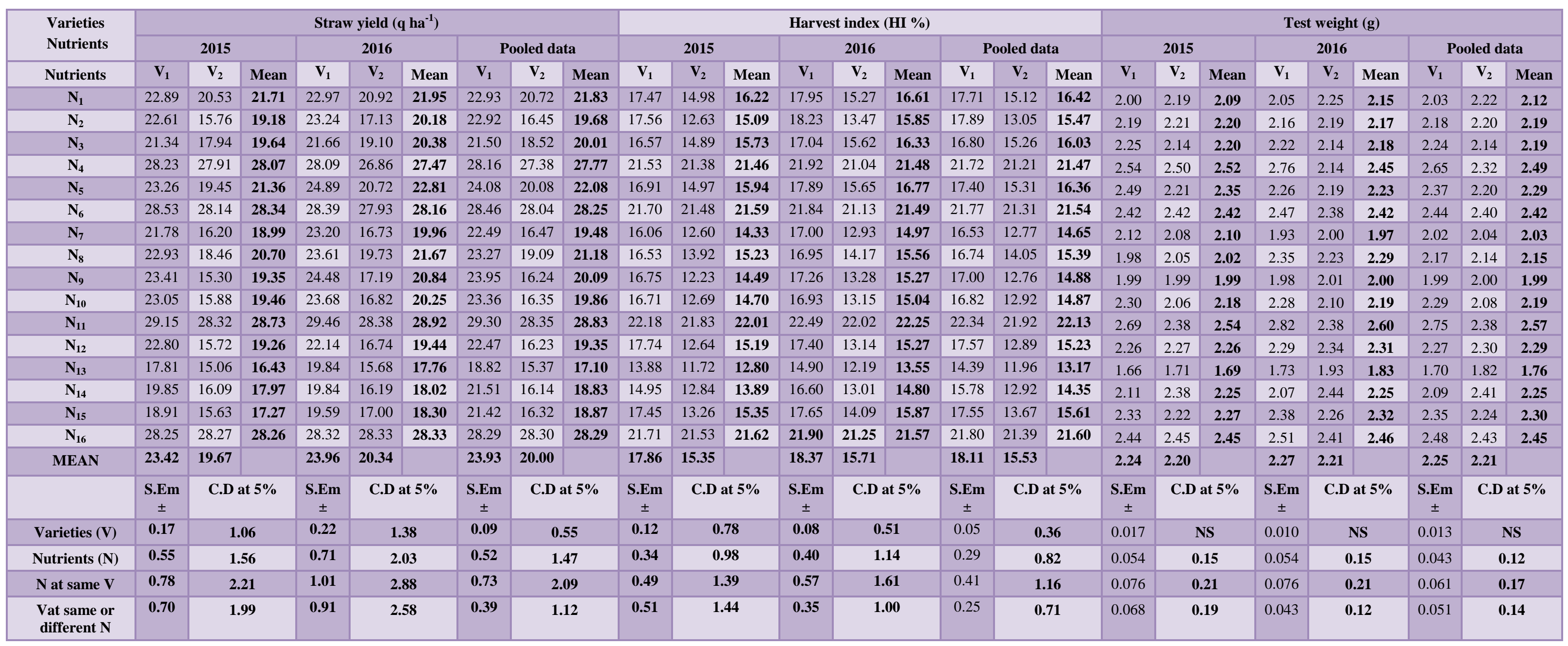


Azotobactor has nitrogen fixing potential as Nitrogenase activity of rhizosphere soils on different treatments Isabgol rhizosphere (Saxena and Rao, 2000).

Significantly higher harvest index (22.34) was recorded with Vallabh Isabgol-1 supplied with $75 \%$ RD of FYM + $75 \%$ RD of NPK + Azospirillum + PSB $+\mathrm{ZnSO}_{4}+\mathrm{FeSO}_{4}\left(\mathrm{~N}_{11}\right)$, which was on par with $\mathrm{V}_{2} \mathrm{~N}_{11}(21.92), \mathrm{V}_{1} \mathrm{~N}_{16}$ (21.80), $\mathrm{V}_{1} \mathrm{~N}_{4}(21.72), \mathrm{V}_{1} \mathrm{~N}_{6}(21.77)$. The lower harvest index (11.96) was recorded in $\mathrm{V}_{1} \mathrm{~N}_{13}$ during the pooled data. This increased yield parameters due the increased seed yield consequence with application of balanced nutrient RD of FYM $75 \%+$ RD of NPK micro nutrients mixed with bio fertilizers like azospirillum mechanism through phosphate dissolution and in the biosynthesis of bioactive in soil. The biofertilizers help in fixation of atmospheric nitrogen, better root proliferation, better availability and absorption of nutrients by the plants, which might have resulted in better growth in plant towards reproductive parameters with accelerating tillers, dry matter production, number of spikes per plant, spikelets per plant, spike length, increase towards yield attributing characters viz. number of seeds per spike and more straw yield production, ultimately all these growth and reproductive yield attributes helped to increase seed yield, husk yield, further the higher economic and biological yield contributed towards increase harvest index. However because of higher seed weight due to higher doses of nutrients use, leads to increase higher functional photosynthetic accumulation, which in turn have resulted in increased seed size and seed filling. Similar findings observed by Repsiene (2001), Yadav et al., (2003), Nadim et al., (2011), Singh et al., (2011), Tripati et al., (2013), Choudhary et al., (2014), Nadukeri et al., (2014), Shirvan et al., (2014) and Shivran et al., (2015). The number of test weight $(\mathrm{g})$ was significantly at harvest stage of crop higher (2.75) was recorded with Vallabh Isabgol-1 supplied with $75 \%$ RD of FYM + $75 \%$ RD of NPK + Azospirillum $+\mathrm{PSB}_{+} \mathrm{ZnSO}_{4}+\mathrm{FeSO}_{4}\left(\mathrm{~V}_{1} \mathrm{~N}_{11}\right)$ which was on par with $\mathrm{V}_{1} \mathrm{~N}_{4}$ (2.65), Further the lowest test weight $(\mathrm{g})$ was recorded in $\mathrm{V}_{1} \mathrm{~N}_{13}$ (1.70) during the pooled data. However because of higher seed test weight due to higher doses of nutrients use, leads to increase higher functional photosynthetic accumulation, which in turn have resulted in increased seed size and seed filling. Similar findings observed by Repsiene (2001).

\section{References}

Choudhary, I. and Shivran, A. C., 2009, Effect of integrated nutrient management on yield quality and nutrient uptake of Isabgol. Ann. Agric. Res. New Series, 30 (3 and 4): 105-107.

Choudhary, T., Sharma, S. K. and Yadav, B. K., 2014, Influence of FYM and inorganic fertilizers on growth and yield of Isabgol (Plantago ovata Forsk.). J. Spices Aromatic Crops, 23 (1): 130-136.

Farooqui, A. A. and Sreeramu, B. S., 2001, A text book an cultivation of medicinal and aromatic crops. Universities Press (India) Ltd., Hyderabad. p.168-174.

Goraya, G.S. and Ved, D. K., 2019, Medicinal plants in India: An assessment of their demand and supply, NMPB, Ministry of AYUSH Government of India and ICFRE Dehradun.

Hindiholi, M. S., 2006, Effect of dates of sowing and nitrogen levels on growth and yield of Isabgol (Plantago ovata Forsk.). M.Sc. (Hort.) Thesis, Univ. Agril. Sci., Dharwad.

Jackson, M.L., 1973, Soil chemical analysis. Prentice hall of India private limited, New Delhi, pp. 485.

Kumar, S. R., Beniwal., B. R. and Choudhary. B. R., 2009, A high yielding Isabgol (Plantago ovata Forsk.) genotype for 
arid western plain of Rajasthan. Annals of Arid Zone, 48(2): 169-170.

Kumar, M., Jakhar, M. S. and Singh, V. P., 2015, Effect of varying nitrogen levels on growth and yield of Isabgol (Plantago ovata Forsk.). Annals of Horticulture, 8 (2): 212-214.

Nadim, M, M., Ahmad, J., Umer, S. and Bakshi, S.K., 2011, Influence of nutrients and microorganisms on the growth and yield of (Plantago ovata Forsk.). Trends in Biosciences, 4 (2): 169-171.

Nadukeri, S., Kattimani, K. N. and Kolakar, S. S., 2014, Influence of organic and inorganic fertilizers on growth and tuber yield of Coleus (Coleus forskohlii Briq.) under northern dry zone of Karnataka. Intl. J. Agric. Sci., 10 (1): 119-123.

Panse, V. G. and Sukhatme, P. V., 1983, Statistical Methods for Agric. Workers. Indian Council of Agric. Res., New Delhi, pp. 152-174.

Patel, K. V., Sushila, A., Patel, S. and Sriram, S., 2005, Standardization of method and evaluation of accession for husk content in Isabgol. J. Medicinal and Aromatic Plants Sci., 27: 243-246.

Patel, A., and Saravanan, R., 2010, Screening of plantago species for physiological parameters in relation to seed yield. Electronic J. Plant Breeding, 1(6):1454-1460.

Piper, C. S., 1966, Soil and plant analysis inter sciences publications, Inc., New York.

Repsiene, R., 2001, Efficiency of placement fertilization for barley yield in conservation agriculture a worldwide Challenge. First World Congress on Conservation agriculture; Madrid, Spain, 2: 327-330.

Raissi, A., Galavi, M., Ramroudi, M. and Roholla, S., 2012, Effects of phosphate bio-fertilizer organic manure and chemical fertilizers on yield yield components and seed capabilities of Isabgol (Plantago ovate). Intl. J. Agri. Crop Sci., 4(24): 1821-1826.

Salmasi, S, Z., Behrouznajhad, S. and Golezani, K. G., 2012, Effects of foliar application of $\mathrm{Fe}$ and $\mathrm{Zn}$ on seed yield and mucilage content of Psyllium at different Stages of maturity. International Conference on Environment, Agriculture and Food Sciences. (ICEAFS'), Phuket, Thailand.

Saxena, A. and Rao, A. V., 2000, Response of Isabgol to aztobacter inoculation under field condation in arid zone. Annals of Arid Zone, 39(2): 199-201.

Shivran, A. C., Choudhary, I. and Puniya, M. M., 2014, Influence of integrated nutrient management and biofertilizer on growth yield and soil fertility of blond Psyllium (Plantago ovata Forsk.) cultivation under semi-arid conditions. Ann. Agric. Res., New Series. 35 (4): 379-385.

Shivran, A. C. and Jat, N. L., 2015, Integrated nutrient management influenced growth yield and economics of Fennel (Foeniculum vulgare) under semi-arid conditions. Ind. J. Agronomy, 60 (2): 318-323.

Shivran, A. C., 2016a, Response of bond Psyllium (Plantago ovata Forsk.) varieties to time of sowing and nitrogen fertilization under semi-arid condition. Intl. J. Seed Spices., 6 (2): 50-54.

Shivran, A. C., 2016b, Growth yield and nutrient uptake of Isabgol (Plantago ovata Forsk.) with phosphorus PSB and zinc fertilization. Intl. J. Seed Spices, 6 (1): 66-73.

Shivran, A. C., Choudhary, I. and Puniya, M. M., 2014, Influence of integrated nutrient management and biofertilizer on growth yield and soil fertility of blond Psyllium (Plantago ovata 
Forsk.) cultivation under semi-arid conditions. Ann. Agric. Res., New Series. 35 (4): 379-385.

Singh., S.B., Chauhan. and Vishwanath, 2011, Evaluation of Isabgol (Plantago ovata Forsk.) varieties to potash levels in semi-arid condition. The J. Rural \& Agric. Res., (2): 58-59.

Stanford, S. and English., 1963, Use of flame photometer in rapid soils tests for potassium and calcium. Agronomy. J., 41: 446-447.

Tripathi, V. K., Sanjeev Kumar, Katiyar, P. N. and Nayyer, M.A., 2013, Integrated nutrient management in Isabgol
(Plantago ovata Forsk.). Progressive Horticulture, 45: 302-305.

Tyagi, S., Singh, O. P., Kumar, A., Sahay, S., Nanher, A, H. and Mishra, P, K., 2016, Studies on the performance of Isabgol (Plantago ovata Forsk.) genotypes under uttar pradesh condition. Research Environ. life. Sci., 9 (10): 1239-1241.

Yadav, R.D., Keshwa, G.L. and Yadav, S. S., 2003, Effect of integrated use of FYM, urea and sulphur on growth and yield of Isabgol (Plantago ovata Forsk.). J. Medicinal and Aromatic Plants Sci., 25: 668-671.

\section{How to cite this article:}

Siddalingayya V. Salimath, K. N. Kattimani Y. K. Kotikal, Md Jameel Jhalegar, J. Venkatesh, D. R. Patile and Nagarja, N. S. 2019. Influence of Varieties and Integrated Nutrient Management on Yield Parameters of Isabgol (Plantago ovata Forsk.) under Northern Dry Zone of Karnataka, India. Int.J.Curr.Microbiol.App.Sci. 8(09): 2031-2041. doi: https://doi.org/10.20546/ijcmas.2019.809.235 